\title{
The Protea Species of the Summer Rainfall Area of South Africa.*
}

\author{
By \\ J. S. Beard. \\ INTRODUCTORY.
}

The genus Protea, R. Br. (nom. cons.), is distributed throughout Africa south of the Sahara with two main centres of distribution, the Cape fynbos and the Central African Brachystegia belt which stretches from Angola through the Rhodesias into Tanganyika. The former contains about 70 species, and the latter, as at present known, about 50. Four species only which are not represented within the tropical Brachystegia belt occur to the north of it, bringing the total for tropicals up to 54 . For the summerrainfall area of South Africa, which we may designate the sub-tropical belt linking the tropical and Cape centres of distribution, this paper will deal with 12 endemic species, bringing the total for the genus to 136 . These are, therefore, equally divided between the Cape and the rest of Africa.

The summer rainfall area of South Africa is, for Proteas, essentially a transitional region and is thus in many ways of special interest. It is much poorer in species than the main centres to north and south which it links and the individual plants are less conspicuous in the landscape. Of the 15 species concerned, one ( $P$. lacticolor) is essentially a Cape fynbos species which extends its range into the southern part of our area, and two $(P$. gaguedi and $P$. hirta) are tropical species of very wide distribution which come down into Natal. The remaining 12 species are endemic to the summer-rainfall area. None of them enters Cape vegetation to the southward or tropical vegetation to the north. Two of them, $P$. subvestita and $P$. rouppelliae, are of Cape affinity, belonging to sections of the genus (Exsertae, Ligulatae) otherwise only represented among Cape fynbos species. Nine others belong to the typically tropical sections Lasiocephalae and Leiocephalae, while three belong to a new section which it is proposed to recognize, the Patentiflorae, which also contains a number of tropical species.

\section{TAXONOMY.}

There have been only two complete treatments of the genus Protea in South Africa since R. Brown's work in 1810: Meisner in de Candolle's Prodromus, 1856, and Phillips and Stapf in the Flora Capensis Vol. V of 1913. The latter is therefore the foundation on which this paper rests. The taxonomy of Protea is in general very difficult and confused due to the horticultural popularity of the genus in Europe in the late eighteenth century and the consequent large amount of literature from that period. Fortunately for the present study, the summer-rainfall area Proteas were not discovered early enough to share in that confusion, and it is only one solitary intruder from the Cape flora, $P$. lacticolor Salisb., which is likely to present difficulty. It may be remarked that whoever sets out to revise the Cape Proteas will have to undertake some very laborious research into the eighteenth century work.

* (Preliminary account presented to the Annual Congress of the S.A. Association for the Advancement of Science, Nelspruit, 1956.) 
Phillips and Stapf divided the South African species of Protea into 12 sections, arranged in two major groups; the first of these contained eight of the sections and consisted of arborescent plants, while the remaining four sections were placed in a group of suffrutescent plants having underground rootstocks. In the writer's opinion this major grouping is artificial and separates sections that should properly be united. We find the majority of summer rainfall species fall into the sections Ligulatae, Exsertae, Lasiocephalae and Leiocephalae, a treatment which it is proposed to follow. However, there are a number of dwarf species which would have to be placed among the Microgeantheae if Phillips and Stapf were followed literally: instead, they have been placed among the Leiocephalae where they clearly belong naturally. Furthermore, there are several others which may assume either a dwarf or arborescent habit according to growing conditions and degree of veld-burning.

Two of the newly discovered species described here, $P$. comptonii and $P$. rubropilosa, while closely related to one another, do not fit readily into any of the sections of Phillips and Stapf: their heads are much larger than in the Lasiocephalae and Leiocephalae, yet they are very distinctly different from any of the large-headed Cape sections. A curious feature, taken as diagnostic, is that the heads do not close again after anthesis while the fruit is maturing but remain wide open or everted, and the section is thus named Patentiflorae. Both heads and leaves are larger than in the Lasiocephalae and Leiocephalae, whose heads are uniformly closed after anthesis. The previously known species $P$. curvata is placed in this section, which will include also a number of the tropical species, notably $P$. angolensis Welw., $P$. chionantha Engl. and Gilg, $P$. bella Hauman and $P$. madiensis Oliv. The South African species are peculiar in that the growthhabit and bark of the trees and the leaves in the case of $P$. rubropilosa and $P$. comptonii are more typical of Faurea than of Protea, in particular resembling Faurea galpinii.

The treatment in this paper has perforce been based upon specimens in the South African herbaria, supported by a large amount of field study. The types of those species of more antique description are mostly in Europe, but they were obtained on loan for study for which thanks are due to the Directors of the herbaria at Kew, BerlinDahlem, Brussels and Leiden. Typification has been undertaken as prescribed in the international code. None of the authors of the species in question indicated holotypes. In cases where no duplicate specimens of the type have been traced the unicum has been designated the holotype. In other cases a lectotype has been selected, naming as far as possible a specimen which is at Kew or some other European herbarium.

\section{Distribution AND ECOlOGY.}

In mapping the distribution of our species, use may be conveniently made of the vegetation map of the Union by Acocks, "Veld Types of S. Africa ", which accompanies Botanical Survey Memoir No. 28.

The true Cape fynbos which is the real home of the Cape species of Protea is confined to the winter rainfall area west of Uniondale. The constant rainfall zone contains a fynbos mapped as "False Macchia" by Acocks which covers widely the various mountain ranges in the Uniondale, Humansdorp and Port Elizabeth Divisions and is prolonged in a narrow outlying strip along the Zuurbergen, around Grahamstown and at Riebeeck East. This False Macchia is much poorer in Protea species than the true Macchia further west and appears to contain only 19 of them. Fifteen of these do not range east of Uitenhage, the outlying area up to Grahamstown containing four species only.

North and east of this, across the Keiskama river and along the scarp front of the Winterberg and Amatola mountains, summer rainfall vegetation begins in the form of various types of grassveld which continue north right to the Limpopo. Here one can no longer expect to see Proteas more or less anywhere as is the case in the Cape fynbos. Habitats are now much more restricted and the Proteas occur in localised patches. Most of the summer rainfall area is covered with grassveld, which is a fire climax: much of this again is potentially forest, though whether it has ever actually in whole 
or part been forest in recent geological times is another matter. The Proteas do seem to indicate that forest has at least been rather more extensive than it is today. They do not themselves occur, of course, in forest but they are found naturally in conjunction with it. In many places today where there are forests on mountain sides one can study this conjunction. At the foot of the slopes the forest is on deep soil and is very luxuriant; higher up the soil becomes more and more shallow and rocky, and the forest is reduced in stature. Eventually, if the mountain is capped by extremely steep and rugged slopes, rock slabs or krantzes, the forest gives way abruptly to an open Protea woodland. There is little doubt from the relics that occur in protected situations that this open Protea woodland as we now see it is a remnant, decimated by fire, of a Macchia floristically and physiognomically similar to the Cape fynbos. Acocks several times gives lists of associated Macchia species: various Ericaceae and Widdringtonia spp. were undoubtedly prominent but have been largely eliminated by fire. The Proteas are relatively fire-resistant and have survived. None the less there is a limit to their tolerance and all too many of the Protea colonies that one sees today are patently in a state of recession. The forest that they once bordered has long since disappeared, their associated shrubs have gone and now they themselves are threatened with extinction as the constant fires repeatedly eliminate their seedlings.

This ecological pattern is typical of the country along and to the east of the eastern escarpment, where we may only look for Proteas in the high rainfall areas and on sites too adverse for forest. In the central and western Transvaal the pattern changes into something much more suggestive of the tropics. Here, certain Protea species inhabit Acocks' Sour Bushveld and Bankenveld: in the former they are general and in the latter occur in the woodland which covers the rocky knolls, in both cases helping to make up a type of savanna woodland of distinctly tropical appearance. As before, however, we still find the Proteas occupying poor, rocky ground in the areas of highest rainfall.

As mentioned above, Acocks' Veld Types map has been drawn upon as an ecological basis for mapping Protea distribution, since the Protea species can be simply correlated with a small and defined number of veld types. The distribution of Proteas is not continuous, in fact it is highly erratic, and to map separately every single isolated locality of occurrence would be a formidable and rather unnecessary task. If, however, it is known in which veld types they are to be found, a map of the distribution of those veld types will divide the country within which locally Proteas may be found from that where they are absent. A "veld type" is not a plant community, it is really a landscape unit containing a mosaic of plant communities. Appropriate veld types contain Protea woodland as one of the components of the mosaic. Proteas occur in montane macchia in the following veld types:-

Acocks' Type 1, Coastal Forest and Scrub. 3, Pondoland Coastal Plateau Sourveld. 44, Highland Sourveld, with its unnumbered subdivision to the south, the Dohne Sourveld, and its separately numbered northern subdivision: 8, North-east Highland Sourveld. 45, Ngongoni veld of the Natal Mistbelt. 63, Piet Retief Sourveld (in part).

Proteas occur in savanna woodland in the following: 20, Sour Bushveld. 61, Bankenveld.

A small portion only of the Piet Retief Sourveld is affected, accompanying the escarpment of the Karroo rocks from Wakkerstroom north to the Swaziland border. It is probable that this strip should properly be regarded as a narrow extension of the Highland Sourveld.

With the exception of Protea gaguedi all our species occur within the boundaries of these veld types as mapped, unless here and there some mountain top carries a patch of the veld type too small to be separately mapped. $P$. gaguedi is typical rather of the ecotone between highland sourveld and bushveld and is thus frequently found slightly outside the borders of the above-mentioned veld types. 


\section{Key to Sections.}

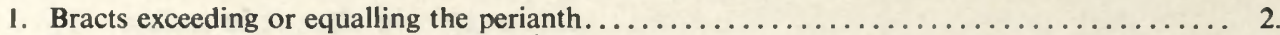

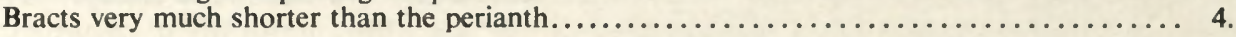

2. Inner bracts spathulate, $2 \mathrm{~mm}$ wide in lower part, broadening to $10 \mathrm{~mm}$ wide at tip...I. Ligulatae.

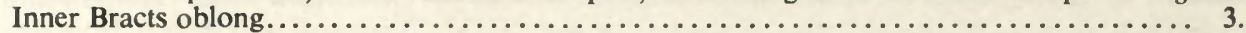

3. Inner bracts pubescent, curved outwards away from the flowers: heads campanulate...II. Exsertae. Inner bracts glabrous, curved inwards to enfold the flowers: heads globose or tur-

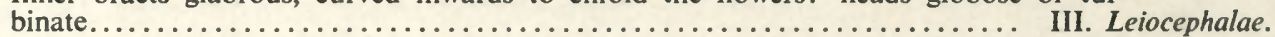

4. Heads conical to globose, closing while the seed is ripening; perianth tube densely

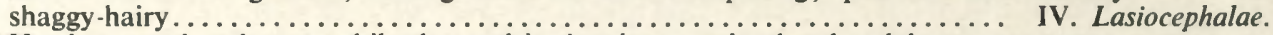
Heads everted and open while the seed is ripening; perianth tube glabrous or at most

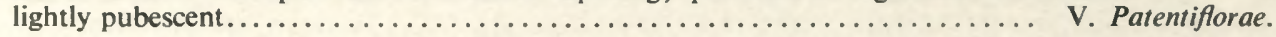

\section{Alternative Key to Sections.}

Based on ratio total length of perianth to length of lip.

1. Ratio $2 \cdot 5$ or less: Lasiocephalae.

2. Ratio 2.5 to 3.0: Ligulatae or Patentiflorae.

Length of teeth $12 \mathrm{~mm}$ : Ligulatae.

Length of teeth 3-4 mm: Patentiflorae.

3. Ratio 3.0 to 3.5: Leiocephalae.

4. Ratio over 4: Exsertae.

\section{Key to SPECIES.}

Section I.-Ligulatae. Heads large, 8-12 cm long, conical, inner bracts red, spathulate, silky-tomentose, exceeding the flowers.

Only species.

1. P. rouppelliae.

Section U.-EXSERTAE. Heads medium-sized, $5-7.5 \mathrm{~cm}$ long, campanulate, inner bracts white or pink, silky-pubescent, recurved at tip, exceeding the perianths but not the styles.

Leaves hairy in youth, distinctly veined: Heads $6-7.5 \mathrm{~cm}$ long, perianth lip

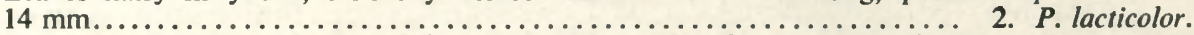
Leaves woolly in youth, indistinctly veined: Heads $5 \mathrm{~cm}$ long, perianth lip $10 \mathrm{~mm}$

3. P. subvestita.

Section III.-Lelocephalae. Heads small to medium-sized, $4-8 \mathrm{~cm}$ long, globose or turbinate, bracts greenish tinged with red, glabrous, slightly incurved, more or less equalling the flowers.

1. Trees or divaricate shrubs: stems compound, flowering branchlets $5-15 \mathrm{~mm}$

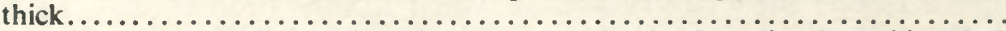
Low shrubs or small creeping plants: stems simple, flowering branchlets $3-5$

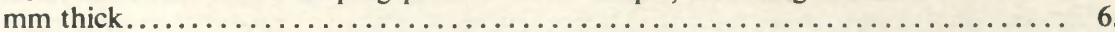

2. Perianth $4 \mathrm{~cm}$ long, tube glabrous within...................... caffra. Perianth $4.5-5 \mathrm{~cm}$ long, tube fulvously hairy within......................

3. Leaves falcate and more than $15 \mathrm{~cm}$ long........... 6a. P. rhodantha var. falcata. Leaves straight and under $15 \mathrm{~cm}$ long............................. 4 .

4. Most leaves less than $2.5 \mathrm{~cm}$ broad.................. 5 . Pultibracteata. Most leaves more than $2.5 \mathrm{~cm}$ broad............................ 5 .

5. Leaves thin, venation prominent: heads $7-8 \mathrm{~cm}$ long... 6. $P$. rhodantha var. rhodantha. Leaves thick, venation indistinct: heads $5-6 \mathrm{~cm}$ long............ $P$. dracomontana.

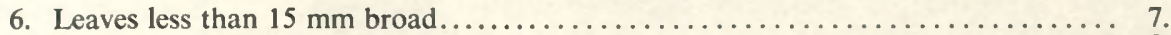
Leaves more than $15 \mathrm{~mm}$ broad............................... 8

7. Stems creeping: leaves all turned to one side of stem and very narrow, 7-10 $\mathrm{mm}$ broad.......................................... 8. P. parvula. Stems erect: phyllotaxis normal, most leaves $10 \mathrm{~mm}$ or more broad..... 9. P. simplex.

8. Leaves less than $25 \mathrm{~mm}$ broad.................................. 9.

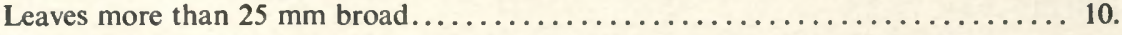

9. Heads $6 \mathrm{~cm}$ long, bracts $5 \mathrm{~cm}$, perianth $4.5 \mathrm{~cm}$, lip $15 \mathrm{~mm} \ldots \ldots 10$. P. transvaalensis. Heads $5 \mathrm{~cm}$ long, bracts $3.5 \mathrm{~cm}$, perianth $3.5 \mathrm{~cm}$, lip $10 \mathrm{~mm} \ldots \ldots \ldots \ldots$..... $P$. simplex.

10. Venation prominent, leaves thin and turning black when dry: perianth lip

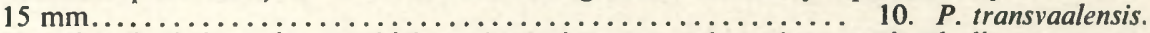
Venation indistinct, leaves thick and turning grey when dry: perianth lip

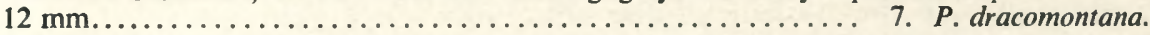


Section IV.-Lasiocephalae. Heads small to medium-sized, 4-8 cm long (rarely to $10 \mathrm{~cm}$ ), conical or globose, bracts greenish, hairy, with silvery or russet pubescence, very much shorter than the flowers.

1. Adult leaves glabrous; bracts covered with dense silvery pubescence; heads always solitary, terminal.......................... 11. P. gaguedi. Adult leaves hairy; bracts with thin silvery to russet pubescence; heads often

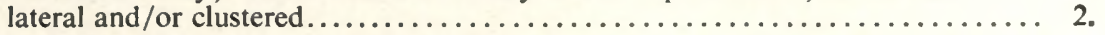

2. Leaves densely clothed with fine silky hairs and with longer russet hairs on the lower half of the midrib and base................ 12a. P. hirta subsp. hirta. Leaves apparently glabrescent but with closely adpressed silky hairs, especially on the base of the midrib................ 12b. P. hirta subsp. glabrescens.

Section V.-Patentiflorae. Heads medium to large, 6-10 cm long, everted, bracts red or green, glabrous or hairy, very much shorter than the flowers.

1. Bracts densely rusty-pilose....................... 13. P. rubropilosa.

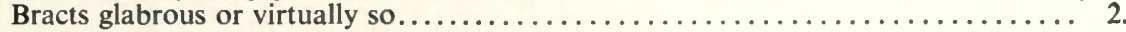

2. Bracts green, flowers white; leaves $3-6 \mathrm{~cm}$ wide........... 14. P. comptonii. Bracts red, flowers pink; leaves $1-1.5 \mathrm{~cm}$ wide.............. 15. P. curvata.

1. P. rouppelliae Meisn. in DC. Prodr. 14: 237 (1856); Phillips in F.C. 5: 573 (1913); Bews in Fl. Natal \& Zululd.: 82 (1921); Burtt-Davy in Fl. Pl. Afr., t. 133 (1924), Fl. Transv.: 211 (1926).

Type: Magaliesberg, Zeyher 1457 (K, holo.!).

Scolymocephalus lanuginosus O. Ktze in Rev. Gen Pl. 3: 279 (1891).

Protea lanuginosa K. Schum. in Just. Jahresb. 26, 1: 364 (1900).

P. transvaaliensis Gdgr. \& Schinz in Bull. Soc. Bot. de France 50, 4: t. 13 (1913) non

Phillips. Type: Magaliesberg, Laidley 380 (L, iso.!)

P. rudatisii Engl. in Pflanzenwelt Afr. 3, 1: 66 (1915) nomen.

A small, gnarled tree $3-5 \mathrm{~m}$ in height and usually assuming a neat domed form with many spreading branches from a short trunk up to $20 \mathrm{~cm}$ thick. Bark black, rough, deeply fissured. Flowering branchlets 8-12 mm thick, hairy when young, rapidly becoming glabrous and developing a rough black bark. Leaves sessile or so narrowly attenuate at the base as to appear subpetiolate, closely ranked into terminal rosettes densely enveloping the flower heads, dark green, from linear-lanceolate to obovate or even obovate-spathulate, $1 \cdot 5-4 \cdot 5 \mathrm{~cm}$ wide by $6-16 \mathrm{~cm}$ long (average about $2.5 \times 12 \mathrm{~cm}), 5 \mathrm{~mm}$ broad at the base, apex acute, base narrowed; blade leathery, often somewhat stiffened, glabrous and shiny on the upper surface after shedding an initial woolly covering, midrib prominent both sides, secondary venation ditto, reticulate, without a marginal vein. Heads solitary, terminal, 8-12 cm long and as much in diameter, conical, shortly pedunculate, opening to $90^{\circ}$. Receptacle convex, $15 \mathrm{~mm}$ wide. Bracts about 10-seriate, silky-tomentose and ciliate, the outermost brownish, short, ovate, obtuse, often recurved to revolute: middle bracts silvery-pink, obovate, up to $1.5 \mathrm{~cm}$ broad; the innermost $8-10 \mathrm{~cm}$ long, exceeding the flowers, pink to rose, spathulate, only $2 \mathrm{~mm}$ wide in their lower part, widening to $10 \mathrm{~mm}$ at the top. Perianth $7 \mathrm{~cm}$ long of which $1.5 \mathrm{~cm}$ for the base, $3 \mathrm{~cm}$ for the tube and $2.5 \mathrm{~cm}$ for the lip and teeth; base brown, glabrous, dilated, 3-keeled and 7-nerved; tube white, hairy, rather slender; lip densely hairy, from white below to deep red above; teeth covered with pink to crimson hairs, lateral teeth $12 \mathrm{~mm}$, median tooth $8 \mathrm{~mm}$ long. Fertile stamens 3; filaments $1 \mathrm{~mm}$ long, flattened; anthers linear, $3 \mathrm{~mm}$ long; apical glands $0.5 \mathrm{~mm}$ long, oblong, acute; barren stamen acute, eglandular. Style white, $6 \mathrm{~cm}$ long, curved, somewhat flattened, keeled below on the convex side, usually more or less hairy: stigma red, $9 \mathrm{~mm}$ long, slender, apiculate, kneed and bent at the junction with the style. Ovary $4 \mathrm{~mm}$ long. Fruit $15 \mathrm{~mm}$ long clothed with reddish-brown hairs.

Flowering mainly in autumn. 


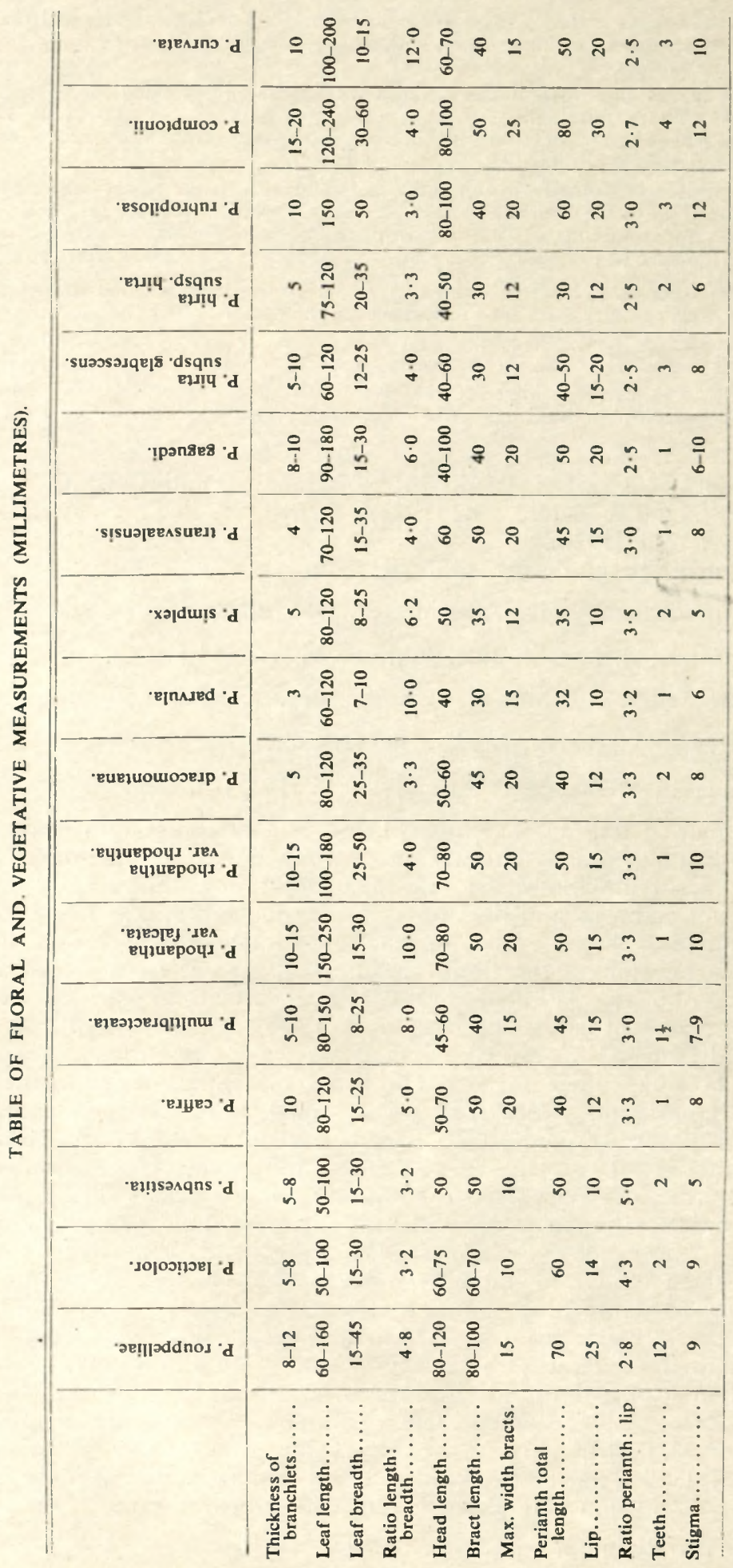


This is one of the most decorative and horticulturally noteworthy of the Proteas under discussion, having large and showy heads of a predominantly red colour. It is also the most widespread in distribution, ranging from Port St. John's to the Zoutpansberg, from sea level to 6-7,000 feet, and found in practically all the mentioned veld types. In the coast belt it ranges only from Port St. John's to Durban, accompanying the outcrop of the Table Mountain sandstone. Inland, this geological preference is abandoned and it ranges almost throughout, being absent from the Dohne Sourveld and the western end of the Transvaal Bankenveld.

There is considerable variation in size and shape of leaves throughout the extended range of this species and also, though to a lesser degree, in the size of the flower heads. As however, these variations are not consistent for given localities, it is considered inadvisable to attempt to recognize varieties. The specimens studied show plants from the Coast and Midlands of Natal frequently to have the largest and softest leaves whereas those from the Central Transvaal and the Waterberg are of the opposite extreme with short, stubby leaves, very stiff. North-eastern Transvaal and upper Natal specimens tend to be intermediate, with specially narrow-leaved types from East Griqualand. The size of flower-heads is reduced in unfavourable situations and vice-versa. Transvaal specimens appear to have the bracts more noticeably silver-tomentose without than Natal specimens, while along the eastern Transvaal escarpment heads are markedly green coloured, red being limited to the lip, stigma and tip of the bracts.

\section{Selected Citations.} 2547.

CAPE.-Matatiele: Baur 4975. Maclear: Galpin 6822. Port St. John's: Sim

Orange Free State.-Harrismith: Witzieshoek, Flanagan 1849.

Basutoland.-Mafube: Dieterlen 946.

Natal.-Nkandhla: Qudeni, Gerstner 1862. Pietermaritzburg: Table Mt., McLean 145. Inanda: Groenberg, Medley Wood 7918.

SwazIland.-Dalriach: Bolus 12266. Mbabane: Burtt-Davy 2789.

TransvaAl.-Pietersburg: Blouberg, Codd and Dyer 8980; 8984; Strydpoortbergen, Maguire 912 . Rustenburg: Magaliesberg, Zeyher 1457; Laidley 380. Krugersdorp: Mogg 20259; 23204. Belfast: Galpin 13091. Lydenburg: Sekukuniland, Barnard 311. Soutpansberg: Galpin 14950. Pietersburg: Houtbosch, Bolus 10951 . Pilgrim's Rest: Graskop, Galpin 14486. Barberton: Burtt-Davy 353.

2. P. lacticolor Salisb. in Parad. Lond. t. 27 (1806); Phillips in F.C. 5: 578 (1913).

Protea orientalis Sim in For. Flor. Cap. 296: t. 128 (1907).

Type: Pirie, Sim 1478 (BOL, CTM, iso.!).

A small spreading tree up to $4 \mathrm{~m}$ in height generally with a neat, domed form. Trunk up to $20 \mathrm{~cm}$ in diameter with grey smooth bark, horizontally ringed. Flowering branchlets $5-8 \mathrm{~mm}$ thick, somewhat woolly-hairy in youth, later glabrous with smooth pale brown bark. Leaves sessile, densely crowded into rosettes at the end of the branchlets, dark green, oblong, $1 \cdot 5-3 \mathrm{~cm}$ wide by $5-10 \mathrm{~cm}$ long (average about $2 \cdot 5 \times 8$ $\mathrm{cm}$ ), apex obtuse or subacute, narrowed at the base; blade rigid, in youth covered somewhat with hairs which later disappear or persist only on the midrib or base, minutely punctate, distinctly veined: midrib yellow, slightly prominent both sides. Axillary buds conspicuous. Heads solitary, terminal, fairly constant in size, $6-7 \cdot 5 \mathrm{~cm}$ long and as much in diameter when open, sessile, campanulate, expanding only to a narrow angle, enclosed by a few bracteolar foliage leaves. Receptacle flat to slightly convex, 
12-15 mm wide. Bracts 6-8 seriate, the outer pinkish or greenish-brown, acute, silkypubescent, ciliate and with an apical tuft of hairs: the inner either white or pink, $1 \mathrm{~cm}$ wide at broadest, tips obtuse, white-ciliate, recurved outwards, 6-7 cm long, exceeding the perianths but not the styles. Perianth very slender and thin in the upper half which is eventually spirally coiled up and withdrawn from the styles, reddish-hairy except at the base, $6 \mathrm{~cm}$ long of which $18 \mathrm{~mm}$ for the base, $28 \mathrm{~mm}$ for the tube and $14 \mathrm{~mm}$ for the lip; lip glabrous, 3-toothed; lateral teeth 1.5-2 $\mathrm{mm}$ long, red or white hairy; stamens all fertile, subsessile; anthers linear, $9 \mathrm{~mm}$ long, apical glands $\frac{1}{3} \mathrm{~mm}$ long, ovate, obtuse, swollen on the inner face. Style white, glabrous, $6.5 \mathrm{~cm}$ long, straight, tapering above, compressed below, subterete above, grooved on one side; stigma red or white, very slender, $9 \mathrm{~mm}$ long passing with an abrupt thickening into the style. Ovary $3 \mathrm{~mm}$ long. Fruit curved, $5 \mathrm{~mm}$ long clothed with long brown hairs.

Flowers in late summer (February to April).

This species is essentially an inhabitant of the Cape fynbos from Worcester to Uitenhage, entering the summer rainfall area in the Amatola and associated mountains.

Its taxonomic identity has been accepted without critical study, following Phillips in Flora Capensis. The original description was in 1806 and the name ("milkcoloured ") refers to the white colour of the heads. Actually pink-headed forms seem to be at least equally common. Perhaps for this reason Meisner changed the name to $P$. latericolor (" brick-coloured ").

\section{Selected Citations.}

CAPE.-Stockenstroom: Katberg, Dyer 369. Keiskamahoek: Hogsback, Beard 759. Stutterheim: Mountains, Flanagan 1703. King William's Town: Pirie, Sim 1478.

Phillips and Stapf in Fl. Cap. recognise a variety orientalis of $P$. lacticolor, based upon a reduction of $P$. orientalis $\operatorname{Sim}$ of which the type is Sim 1478. After examining this specimen I am unable to establish any points of difference from the type of $P$. lacticolor and accordingly cannot recognise the variety.

3. P. subvestita N.E. Br. in Kew Bull. 1901: 132; Phillips in F.C. 5: 578 (1913); Bews in Fl. Natal \& Zululd. (1921).

Type: Faku's Territory (Pondoland), Sutherland s.n. (K, holo.).

The description given above for $P$. lacticolor serves for $P$. subvestita likewise, with the following amendments:-

Branchlets distinctly woolly-hairy in youth. Leaves covered in youth with a dense woolly layer which is later dehiscent, leaving the blade glabrous or almost so: leaves rather more fleshy, so that venation is indistinct except sometimes on the upper surface and the blade can no longer be seen to be minutely punctate. Heads and flowers shorter. Heads $5 \mathrm{~cm}$ long, perianth rather more thickly hairy, teeth of the lip white-woolly. Perianth $5 \mathrm{~cm}$ long of which $15 \mathrm{~mm}$ for the base, $25 \mathrm{~mm}$ for the tube and $10 \mathrm{~mm}$ for the lip. Anthers $5 \mathrm{~mm}$ long. Style $5 \mathrm{~cm}$, stigma $5 \mathrm{~mm}$.

P. subvestita $\mathrm{R}$. Br. is so close to $P$. lacticolor that there was some temptation to reduce it in rank as a geographical subspecies. The distinguishing differences are merely such as one would expect to be associated with life at higher altitude in a more rigorous climate. $P$. subvestita is common on high mountains throughout the Highland Sourveld proper, seldom much below the 6,000 feet contour and favouring the steepest and most rocky places. None of the species of this section appear to have much fire resistence and are confined to sites where fires are less fierce. 


\section{Selected Citations.}

CAPE.-Xalanga: Cala Mission, Pegler 1650. Maclear: Tent Kop, Galpin 6824. Umtata: Baziya Mountain, Baur 624.

Basutoland.-Near Qacha's Nek: Dieterlen 993.

NATAL-CUnderberg: McClean 678. Estcourt: Cathkin Park, Galpin 11748. Bergville: National Park, Pardoe, s.n. Klip River: Nr. van Reenen, Medley Wood 5631. Nkandhla: Qudeni, Gerstner 3945.

Note.-Protea mundii Klotzsch in Otto \& Dietr. Gartenzeit. 1838: 113.

This is a winter rainfall species to which two collections from the summer rainfall area were wrongly allocated by Phillips in Fl. Cap.: Baur 624, the Baziya Mts., Umtata, and Flanagan 1703, mountains near Stutterheim. I have examined both abovenumbered specimens in CTM and the former is $P$. subvestita, the latter P. lacticolor. It is noteworthy that Flanagan 1703 is also cited in Fl. Cap., with a slightly different locality, under $P$. lacticolor. $P$. mundii has thus never been collected east of van Staaden's Berg. It is very readily distinguished by its capitate stigmas.

4. P. caffra Meisn. in DC. Prodr. 14: 237 (1856); Phillips in F.C. 5: 585 (1913); Fl. Pl. Afr. t. 22, (1921), as $P$. abyssinica, in error; Burtt-Davy in Fl. Transv. 211 (1926).

Type: Magaliesberg, Zeyher 1458 (P. lecto.!, CTM, iso.!).

A small gnarled tree up to $5 \mathrm{~m}$ in height, usually assuming a fairly neat domed form with many spreading branches from a short trunk up to $20 \mathrm{~cm}$ thick. Bark black, rough, deeply fissured. Flowering branchlets $10 \mathrm{~mm}$ or more thick (drying to less), grey-brown, glabrous. Leaves sessile, closely ranked on the flowering branchlets, pale green drying to grey-green, lanceolate or oblong-lanceolate, $1.5-2.5 \mathrm{~cm}$ wide by $8-12 \mathrm{~cm}$ long (average about $2 \times 10 \mathrm{~cm}$ ), $5 \mathrm{~mm}$ broad at the base, apex subacute or obtuse, narrowed towards the base; blade leathery, stiff, glabrous, with a thin cartilaginous margin, midrib yellow, prominent both sides, secondary venation very indistinct even in dried specimens. Heads solitary, terminal, 5-7 cm long and as much in diameter, broadly globose, pedunculate with a rather solid woody stipes $1.5 \mathrm{~cm}$ long, opening to $90^{\circ}$. Receptacle slightly convex, $25 \mathrm{~mm}$ wide. Bracts 5 -seriate above the stipes, at first very finely silky-tomentose, soon glabrous; those on the stipes scaly, greenish or brown, outer bracts of the head greenish developing brown tips, inner pink to red, obtuse, up to $5 \mathrm{~cm}$ long and $2 \mathrm{~cm}$ broad, slightly shorter than the flowers. The bracts are somewhat woody in this species. Perianth pinkish-white, glabrous except for fugacious hairs on the lip spirally coiled up and withdrawn in mature heads $4 \mathrm{~cm}$ long of which $12 \mathrm{~mm}$ for the base, $16 \mathrm{~mm}$ for the tube, and $12 \mathrm{~mm}$ for the lip; lateral teeth $1 \mathrm{~mm}$ long, median tooth under $1.5 \mathrm{~mm}$; teeth tufted with fugacious tawny-white hairs. Stamers all fertile; filaments $0.5 \mathrm{~mm}$ long, flattened, concave; anthers linear, $9 \mathrm{~mm}$ long. Style white, $4 \mathrm{~cm}$ long, curved, tapering, flattened, keeled on both sides, glabrous; stigma $8 \mathrm{~mm}$ long, filiform, passing almost imperceptibly into the style. Ovary $6 \mathrm{~mm}$ long. Fruit $12 \mathrm{~mm}$ long, thickened towards the top and bent over, clothed with long brown hairs.

Flowers in summer (November to February).

Protea caffra Meisn. is characteristic of rocky ridges in the Transvaal Sour Bushveld and Bankenveld, to which areas it is confined except for outliers in the Lulu Mts. of Sekukuniland, and the mountains of the Leribe district of Basutoland. The specimens from these outlying areas have been very critically examined and are definitely $P$. caffra. In all cases this species inhabits drier, colder conditions than its relatives. 


\section{Selected Citations.}

Basutoland.-Leribe: Dieterlen 319*.

TransvaAl.-Waterberg: Naboomspruit, Galpin 11665 . Rustenburg: Magaliesberg, Zeyher 1458. Krugersdorp: Mogg 20258. Heidelberg: Leendertz 7682. Pietersburg: Strydpoortberge, Welcome Mine, Beard 859. Lydenburg: Lulu Mts., Mogg 16885.

5. P. multibracteata Phillips in Kew Bull. 1910: 230; Phillips in F.C. 5: 586 (1913); Bews in Fl. Natal \& Zululd. 82 (1921).

Type: British Kaffraria, Cooper 86 (K, lecto.!).

Protea pegleri Phillips in Kew Bull. 1910: 230. P. natalensis Phillips 1.c.: 231. P. baurii Phillips 1.c.: 232. P. flanaganii Phillips l.c.: 232, in part from syntype; Gwenkala River, Flanagan 804 (CTM).

An irregular gnarled tree $1-5 \mathrm{~m}$ in height. Trunk up to $15 \mathrm{~cm}$ thick, bark black, thick and fissured. Flowering branchlets $5-10 \mathrm{~mm}$ thick, glabrous, at first greenish or reddish. Leaves sessile, often fairly closely ranked at the ends of the branchlets, light green, from narrowly oblong to linear, $8-25 \mathrm{~mm}$ wide by $8-15 \mathrm{~cm}$ long (average about $12 \mathrm{~cm}$ long, width highly variable), sometimes somewhat falcate, apex subacute to subobtuse, narrowed at the base, sometimes so much as to appear sub-petiolate; blade soft, quite glabrous, midrib red, prominent both sides, secondary venation inconspicuous in fresh leaves, moderately conspicuous, finely reticulate and prominent both sides in dried specimens, uniting near the margin but with no true marginal vein. Heads terminal, solitary (or in some Eastern Cape specimens, clustered), 4.5-6 $\mathrm{cm}$ long and $5-8 \mathrm{~cm}$ in diameter, turbinate, generally peduncled with a small scaly stripes some $5 \mathrm{~mm}$ long, opening to $160^{\circ}$. Receptacle slightly convex, $15-20 \mathrm{~mm}$ wide. Bracts about 7-seriate above the stipes, the outer green, at first with a glaucous bloom, the inner greenish to red, colour variable; maximum width $1.5 \mathrm{~cm}$ (or $2 \mathrm{~cm}$ in-some very large heads), $4 \mathrm{~cm}$ long, equalling or slightly shorter than the styles, oblong, obtuse. Perianth white, fulvously hairy within the tube, the lip edged with fugacious pink or brownish hairs, either densely or tipped only; perianth otherwise glabrous, $4.5 \mathrm{~cm}$ long of which $12 \mathrm{~mm}$ for the base, $18 \mathrm{~mm}$ for the slender tube and $15 \mathrm{~mm}$ for the lip; lateral teeth $1.5 \mathrm{~mm}$ long, median $1 \mathrm{~mm}$; stamens all fertile, subsessile, anthers linear, $8 \mathrm{~mm}$ long; the perianth spirally coiled up and withdrawn in mature flowers. Style white, 5-6 cm long, slightly curved or wavy, somewhat compressed, glabrous; stigma usually pink, 7-9 $\mathrm{mm}$ long, filiform, obtuse, passing almost imperceptibly into the style. Ovary $3 \mathrm{~mm}$ long. Fruit $12 \mathrm{~mm}$ long clothed with golden-brown hairs.

Flowers in summer (November to February).

$P$. multibracteata Phillips ranges throughout Natal and the eastern Cape in all the mentioned veld types, from the steamy flats of the Zululand coast to the Drakensberg at 7,000 feet. and south to the Amatola Mts. This is a moderately severe habitat, with some extremes of heat and cold, less cold but much hotter than that of $\boldsymbol{P}$. caffra. It is everywhere accompanied by the dwarf $P$. simplex Phillips.

The width of the leaves varies considerably in this species, being typically very narrow at the southern end of the range and growing steadily broader towards the north. The distribution is not in contact at any point with either $P$. caffra or $P$. rhodantha.

* One of the two sheets of this number in the Natal Herbarium is $P$. dracomontana Beard. 


\section{Selected Citations.}

CAPE.-Kentani: Pegler 1872. Komgha: Gwenkala River, Flanagan 804. Port St. John's: Hutchinson 1828. British Kaffraria: Cooper 86. Stockenstroom: Katberg, Dyer 370. Matatiele: Baur 4839.

Orange Free State.-Drakensberg, Orange Free State: Cooper 951.

Natal.-Umzinto: Umtwalumi, Beard 745. Pinetown: Springfield, Medley Wood 12822. Eshowe: Gerstner 1863. Stanger: Tugela Beach, Johnson 390; 620. Richmond: Beard 746. Bergville: National Park, Bayer and McClean 141; Calhedral, Killick 1061. Nkandhla: Qudeni, Bayer 791. Vryheid: Hlobane, Johnstone 436. Ubombo: Lebombo Mts., Sargent s.n.

Swaziland.-Lebombo Mts. S. of Stegi: Verdoorn 1679.

TransvaAl.-Amersfoort: Wakkerstroom, Beard 747.

Phillips in Flora Capensis sustained $P$. multibracteata, reducing to synonymy $P$. pegleri, $P$. natalensis and $P$. baurii which had been simultaneously published in 1910 . $P$. flanaganii is now also reduced as it has not been possible to establish a separate identity for this species in the field (see further discussion under $P$. simplex).

6. P. rhodantha Hook. f., var. rhodantha, in Bot. Mag. t. 7331 (1893); Phillips in F.C. 5: 586 (1913); Burtt-Davy in Fl. Transv. 211 (1926).

Type: Cultivated at Kew, Horn s.n. (K, holo.!).

Protea bolusii Phillips in Kew Bull. 1910: 231.

Type: Forbes Reef, Bolus 12265 (BOL, iso.!).

P. stipitata Phillips 1.c. 1934: 104.

Type: Haenertsburg, Murray s.n. (PRE, iso.!).

Tree up to 15 feet in height, commonly rather less, branching low down and of rambling habit, trunk up to $50 \mathrm{~cm}$ thick, bark black, fissured, warty. Flowering branchlets $10-15 \mathrm{~mm}$ thick, glabrous, with smooth bark, at first green or pinkish, soon pale brown. Leaves sessile, crowded towards the end of the branchlets, green, oblong to oblanceolate, often slightly falcate or oblique, $2.5-5 \mathrm{~cm}$ wide by $10-18 \mathrm{~cm}$ long (average about $3.5 \times 14 \mathrm{~cm}$ ), apex subacute, narrowed at the base; blade leathery, quite glabrous, with thin, transparent, cartilaginous margin, midrib red or yellow, prominent both sides, secondary venation reticulate, prominent both sides in dried specimens, with no true marginal vein. Heads terminal, solitary, or, rarely, clustered, $7-8 \mathrm{~cm}$ long and $12 \mathrm{~cm}$ in diameter, turbinate, pedunculate with a well-marked scaly stipes $1 \mathrm{~cm}$ long, opening to $180^{\circ}$ at anthesis. Receptacle slightly convex, $25 \mathrm{~mm}$ wide. Bracts about 6-seriate above the stipes, the outer ovate, subacuminate, green or more or less pink, at first silky-pubescent below, ciliolate; inner oblong, deep rose-colour, glabrous, up to $2 \mathrm{~cm}$ wide and $5 \mathrm{~cm}$ long, equalling or slightly shorter than the flowers. Perianth white suffused with pink, glabrous except within the tube where it is fulvously hairy and at first on the lip, $5 \mathrm{~cm}$ long of which $15 \mathrm{~mm}$ for the base, $20 \mathrm{~mm}$ for the tube and $15 \mathrm{~mm}$ for the lip; tube expanded below, slender above, spirally coiled up in old flowers; lip clothed at first with orange hairs, soon glabrous; teeth subequal, recurved, $1 \mathrm{~mm}$ long. Anthers linear, $10 \mathrm{~mm}$ long. Style pink or white, $5.5 \mathrm{~cm}$ long, distinctly swollen just above the ovary, stout when fresh, when dry becoming compressed, grooved or quadrangular, curved, glabrous; stigma $10 \mathrm{~mm}$ long, filiform, slightly wavy at the junction with the style. Ovary $3 \mathrm{~mm}$ long. Fruit $12 \mathrm{~mm}$ long clothed with goldenbrown hairs.

Flowers in summer (December to March). 
P. rhodantha Hook. $f$. is characteristic of the north-east Highland Sourveld and thus of the eastern Transvaal and Swaziland. The habitat is wetter and milder than that of $P$. multibracteata and more genial than that of $P$. caffra. At the southern end of its range in the Barberton mountains and Swaziland this species is represented by its variety falcata in which the leaves become much longer, narrower and curved.

\section{Selected Citations.}

Swaziland.-Forbes Reef: Bolus 12265. Mbabane: Compton 26343.

TransvaAl.-Soutpansberg: Between Rumble's farm and Lejuma Peak, Reynolds 4109; Entabeni, Obermeyer 872. Pietersburg: Haenertsburg, Murray s.n.; Wolkberg, Beard 861. Pilgrim's Rest: Beard 871; Horn s.n.; Mauchsberg, Smuts and Gillett 2261. Barberton: Meeuse 10107.

This species has been most difficult to elucidate. Protea rhodantha (the " redflowered ") was figured in the Botanical Magazine in 1893 with a description by Sir Joseph Hooker from a plant raised at Kew, the seed having been presented by $\mathrm{Mr}$. W. J. Horn in 1886, collected at Pilgrim's Rest in the Transvaal. Unfortunately it is somewhat likely that a plant raised in a Kew greenhouse would differ from its wild prototype, particularly in point of size: furthermore the type material that has been preserved is inadequate, consisting only of a single leaf $14.5 \times 3 \mathrm{~cm}$ in size and a small head, detached and bisected, $5 \mathrm{~cm}$ long and $5 \mathrm{~cm}$ in diameter. It is hardly surprising that the species has been imperfectly understood.

In 1906 a collection of Dr. Bolus, No. 12265, was compared by him at Kew with the above type material of $P$. rhodantha and determined as that species. In Kew Bull. 1910 Phillips erected a new species, $P$. bolusii, upon this specimen but in Fl. Cap. (1913) reduced it to synonymy under $P$. rhodantha. The Bolus collection and the type are the only specimens cited in Fl. Cap. under $P$. rhodantha. In recent years specimens of a taxon found in the Natal Drakensberg have been referred to $P$. rhodantha on the authority of Kew, but no plants occurring in the Pilgrim's Rest district or elsewhere on the Transvaal Drakensberg have, so far as I am aware, been attributed to that species. In 1934 Phillips described a new species, P. stipitata, from Haenertsburg, "aff. $P$. rhodanthae Hook. f. sed foliis et capitulis majoribus, involucri bracteis numerosioribus inferne dense et molliter tomentosis differt".

The essential step towards an understanding of $P$. rhodantha was clearly an investigation as to what Proteas of the section Leiocephalae could be found in the Pilgrim's Rest district. This was carried out by Dr. A. D. Meeuse and myself in February, 1957, after first visiting at Haenertsburg the type localities of $P$. stipitata and $P$. transvaalensis and collecting them in flower. $P$. stipitata was found to be very common near Pilgrim's Rest, to the west on the road to Ohrigstad, to the east at Kowyn's Pass below Graskop and to the south all along the eastern slopes of the Mauchsberg and Mt. Anderson. At the very summit of Mt. Anderson some dwarf plants were found, sterile but apparently $P$. transvaalersis, and at the summit of the Long Tom Pass others, also sterile but demonstrably $P$. parvula.

The latter is distinctly different from $P$. rhodantha in its creeping habit and exceedingly narrow leaves. $P$. transvaalensis has about the same sized heads and leaves as the type of $P$. rhodantha but its leaves are distinctive, turning black when dried and of different shape: the head also is of different shape, long in proportion to breadth. I1 must be admitted that $P$. stipitata comes closest to $P$. rhodantha. The leaves are a very good match and the floral characters agree if we allow for reduction in size due to stunting in the Kew cultivated specimen. The common and conspicuous distribution of this form near Pilgrim's Rest makes it very likely that its seeds would have been collected by Mr. Horn. It is accordingly concluded that $P$. stipitata falls into synonymy under $P$. rhodantha. 
The Natal Drakensberg specimens belong to a distinct species that is not found in the Pilgrim's Rest district and thus they cannot be $P$. rhodantha. They are placed under $P$. dracomontana.

6a. P. rhodantha Hook. f., var. falcata Beard, var. nov.

Type: Barberton, Beard 810 (PRE, holo.).

A varietate rhodantha foliis subter attenuatissimis, saepe quasi petiolatis, demissis, falcatis tamen subter inflexis, longioribus differt.

At the southern end of the range of this species, in the Barberton mountains, one finds mainly this varietal form which differs from typical $P$. rhodantha only in its very long, drooping and falcate leaves, as follows:-

Leaves frequently so long attenuate at the base as to appear petiolate, grey-green, drooping, very variable as to size and shape, linear-oblanceolate to oblanceolate, almost always falcate or at least curved in the lower half, $1 \cdot 5-3 \mathrm{~cm}$ wide by $15-25 \mathrm{~cm}$ long (average about $2 \times 20 \mathrm{~cm}$ ), apex obtuse, base cuneate; blade glabrous, with a membranous margin, midrib sub-prominent, secondary venation indistinct.

Swaziland.-Ngwenya Mts.: Compton 835 in herb. J. S. Beard. Mbabane: Compton 23825.

TransvaAl.-Barberton: Makonjwa Mts., Beard 810; Meeuse 10117; Pott 5676; Clarke s.n.

\section{P. dracomontana Beard, sp. nov.}

Type: Cathedral Peak, Killick 1337 (PRE, holo.!, NH, iso.!).

Frutex divaricata $1-1.5 \mathrm{~m}$ alta, vel saepe nana ramulis simplicibus ex radice crasso editis. Folia elliptica, $3 \mathrm{~cm}$ lata, $10 \mathrm{~cm}$ longa, lamina crassa, rigida, glabra, margine translucente. Capitula terminalia, solitaria vel fasciculata, 5-6 cm longa. Involucri bracteae 5-seriatae, rubrae vel rubrescente-virides, ciliatae, $4.5 \mathrm{~cm}$ longae. Calyx punicea, tubo intus fulvo-piloso, limbo capillis fugacibus cristato. Stylus $4 \mathrm{~cm}$ longus, stigma $8 \mathrm{~mm}$.

Potentially a divaricate shrub up to 1 metre tall, rarely $1.5 \mathrm{~m}$, but most commonly adopting a dwarf form with numerous simple stems $30-50 \mathrm{~cm}$ long arising from a thick rootstock and repeatedly killed back by fire or frost. Shoots woody, $5 \mathrm{~mm}$ thick, bark reddish, glabrous. Leaves bluish-green, sessile, evenly spaced along the shoots, elliptic, $2 \cdot 5-3 \cdot 5 \mathrm{~cm}$ wide by $8-12 \mathrm{~cm}$ long (average about $3 \times 10 \mathrm{~cm}$ ), apex obtuse, base cuneate; blade thick, stiff, quite glabrous, midrib red, prominent both sides in the lower $\frac{2}{3}$ of the leaf, secondary venation inconspicuous, the main veins slightly prominent below; margin translucent. Heads terminal, solitary or clustered, $5-6 \mathrm{~cm}$ long by $7 \mathrm{~cm}$ in diameter, oblong to turbinate, pedunculate with a small scaly stipes $0.5 \mathrm{~cm}$ long, opening to $180^{\circ}$ at anthesis. Receptacle convex, $2 \mathrm{~cm}$ broad. Bracts about 5-seriate above the stipes, red or green edged with red, minutely ciliate, otherwise glabrous, up to $2 \mathrm{~cm}$ broad and $4.5 \mathrm{~cm}$ long, equalling or slightly exceeding the flowers. Perianth pink, fulvously pilose within the tube and on the lip (the latter hairs fugacious), otherwise glabrous, $4 \mathrm{~cm}$ long of which $12 \mathrm{~mm}$ for the base, 16 for the tube and 12 for the lip: teeth subequal, $2 \mathrm{~mm}$ long. Anthers linear, $6 \mathrm{~mm}$ long. Style white, flattened and grooved, $4 \mathrm{~cm}$ long, glabrous: stigma slender, $8 \mathrm{~mm}$ long, slightly wavy at the junction with the style. Ovary $2-3 \mathrm{~mm}$ long. Fruit $12 \mathrm{~mm}$ long clothed with golden-brown hairs.

\section{Plate I.}

Flowers in summer. 
Confined to the Natal Drakensberg from Underberg round to Leribe in Basutoland, at a high level between 6,000 and 8,000 feet elevation, on the basalt.

Basutoland.--Leribe: Dieterlen 319 (in part).

Natal.-Underberg: Himeville, Bew's 36. Estcourt: Giant's Castle, BruynsHaylett 52; Highmoor Forest Reserve, v. Rensburg 4. Bergville: Cathedral Peak, Killick 1638; 1337, Beard 729; Esterhuysen s.n.; Ndedema, Esterhuysen 17367; Mweni, Esterhuysen 14673; National Park, Hutchinson, Forhes and Verdoorn 89; Pardoe s.n.; Edwards 505; 508.

The various collections of this species which exist in S. African herbaria have previously been referred to $P$. rhodantha Hook. f. On acquaintance with the population in the field, it is found to be a distinct taxon differing completely in its broad, fleshy leaves from any of the most nearly related species. As it does not occur in the Pilgrim's Rest district it cannot be $P$. rhodantha and is accordingly named as new.

\section{P. parvula Beard, sp. nov.}

Type: Dullstroom, Galpin 13149 (PRE, holo.!).

Suffrutex caulibus subterraneis, ramulis prostratis glabris. Folia sessilia, erecta, anguste lineare-oblanceolata, $8 \mathrm{~mm}$ lata, $8 \mathrm{~cm}$ longa, saepe aliquantum falcata, apice acuta, ad basin versus attenuatissima. Capitulum $4 \mathrm{~cm}$ longum, stipitatum. Involucri bracteae 5-seriatae, puniceae, glabrae, $3 \mathrm{~cm}$ longae. Calyx alba, glabra capillis paucis, $3.2 \mathrm{~cm}$ longa, limbus dentatus $1 \mathrm{~cm}$ longus, dentes $1 \mathrm{~mm}$, cristati. Stylus $3 \mathrm{~cm}$ longus, glaber, compressus; stigma $6 \mathrm{~mm}$ filiforme, apice obtusum.

A small woody plant with branching underground stems $1-2 \mathrm{~cm}$ thick. Aerial flowering branchlets prostrate, $3 \mathrm{~mm}$ thick, glabrous with pale greenish to reddish bark. Leaves sessile, closely ranked, all turned to an erect position on the same side of the stem, light green, narrowly linear-oblanceolate, $7-10 \mathrm{~mm}$ wide at the broadest point by $6-12 \mathrm{~cm}$ long (average about $0.8 \times 8.0 \mathrm{~cm}$ ), often somewhat falcate, apex acute to sub-rotundate, very long attenuate at the base: blade coriaceous, glabrous, with a thin membranous margin, midrib yellow, prominent below, sub-prominent above; secondary veins fairly distinct, arching and prolonged close to the margin so as to give the impression of a continuous marginal vein. Heads solitary, terminal, $4 \mathrm{~cm}$ long and as much in diameter when open, globose, pedunculate with a slender scaly stipes $7 \mathrm{~mm}$ long, opening to $160^{\circ}$ at anthesis. Receptacle convex, $15 \mathrm{~mm}$ wide. Bracts 5-seriate above the stipes, pale pink, glabrous, up to $15 \mathrm{~mm}$ broad and $3 \mathrm{~cm}$ long, equalling the flowers, obtuse, shortly ciliate. Perianth creamy-white flushed with pink, glabrous except for a variable pilosity along the inner edges of the tube and the tufted teeth; $3.2 \mathrm{~cm}$ long of which $10 \mathrm{~mm}$ for the base, $12 \mathrm{~mm}$ for the tube and $10 \mathrm{~mm}$ for the lip: lateral teeth $1 \mathrm{~mm}$ long with a tuft of hairs. Anthers linear, $6 \mathrm{~mm}$ long. Style white, $3 \mathrm{~cm}$ long, glabrous, compressed and grooved, bulbously swollen above the ovary; stigma $6 \mathrm{~mm}$, slender, obtuse, passing almost imperceptibly into the style. Ovary $2 \mathrm{~mm}$ long. Fruit clothed with long brown hairs.

Flowers in midsummer, (December to January).

This species is among the smallest of the creeping Proteas. It is localised on certain mountain tops in the Eastern Transvaal at 5,500 to 7,000 feet elevation, in very short grassland.

TransvaAl.-Belfast: Suikerboskop, Galpin 13149; Bruce 492. Pilgrim's Rest: Mariepskop, Hebronberg, Beard 868. Lydenburg: Steenkampsberg, Codd 1715; Acocks 12922; Mount Anderson, Smuts and Gillett 2380; Makobulaan, Beard 874. Nelspruit: Kaapsche Hoop, on top of the mountain, Phillips 3464 ; v. d. Merwe 1538. 
9. P. simplex Phillips in Kew Bull. 1910: 230; Phillips in F.C. 5: 588 (1913); Bews in Fl. Natal \& Zululd. 82 (1921); Burtt-Davy in Fl. Transv. 211 (1926).

Type: Maclear, Galpin 6823 (K, lecto. PRE, BOL, GRA, iso.!).

Protea doddii Phillips in Kew Bull. 1911: 82.

Type: East London, Galpin 7936.

P. flanaganii Phillips l.c. 1910: 232 in part, from syntype: Kentani, Pegler 274 (GRA, PRE, BOL, CTM).

A dwarf shrub with a thick underground rootstock from which arise numerous simple, ephemeral erect stems, $5 \mathrm{~mm}$ thick and up to $50 \mathrm{~cm}$ long, glabrous with pink to green bark. Leaves sessile, deep green, arranged all along the shoots, from narrowly oblong to linear, very variable as to size, (especially in width), from $8-25 \mathrm{~mm}$ wide by $8-12 \mathrm{~cm}$ long (average about $16 \mathrm{~mm} \times 10 \mathrm{~cm}$ ), apex subacute to sub-obtuse, base cuneate: blade leathery, glabrous, midrib red or yellowish, prominent both sides, secondary venation prominent. Heads solitary, terminal, $5 \mathrm{~cm}$ long and as much in diameter, turbinate, generally peduncled with a small scaly stipes some $5 \mathrm{~mm}$ long, opening to $160^{\circ}$ at anthesis. Receptacle convex, $15 \mathrm{~mm}$ broad. Bracts about 5-seriate above the stipes, the outer green, the inner greenish to red, $3.5 \mathrm{~cm}$ long and up to 12 $\mathrm{mm}$ broad, equalling or slightly shorter than the styles. Perianth white, fulvously hairy within the tube, the lip edged and tufted with fugacious pink or brownish hairs; perianth otherwise glabrous, $3.5 \mathrm{~cm}$ long of which $10 \mathrm{~mm}$ for the base, $15 \mathrm{~mm}$ for the tube and $10 \mathrm{~mm}$ for the lip; teeth up to $2 \mathrm{~mm}$ long with fugacious tuft of orange hairs. Anthers linear, $6 \mathrm{~mm}$ long. Style white, $4 \mathrm{~cm}$ long, somewhat compressed, glabrous; stigma usually pink, $5 \mathrm{~mm}$ long, filiform, obtuse, passing almost imperceptibly into the style. Ovary $2 \mathrm{~mm}$ long. Fruit $12 \mathrm{~mm}$ long clothed with golden-brown hairs.

Flowers in summer.

Found in the Dohne Sourveld, Highland Sourveld and Coast Belt, accompanying P. multibracteata, also in the N.E. Highland Sourveld in Swaziland.

\section{Selected Citations.}

CAPE.-East London: Dodd in Herb. Galpin 7936. Keiskamahoek: Story 3836. Kentani: Pegler 274; 1871. Lusikisiki: Galpin 10999. Xalanga: Cala, Pegler 1651. Maclear: Galpin 6823.

NatAL.-Inanda: Field's Hill, Medley Wood 12316. Eshowe: Lawn 350. Underberg: McClean 725. Bergville: Champagne Castle, Bayer 1440. Lion's River: Howick, Parkinson s.n. Nkandhla: Qudeni, Gerstner 639. Pietermaritzburg: McClean 153. Umvoti: Greytown, Galpin 14836.

Swaziland.-Mbabane: Bolus 12264; Burtt-Davy 2896. Forbes Reef, BurttDavy 2767.

After field study and consideration of the herbarium material I have come to the conclusion that there is no valid reason for the separation of $P$. doddii which is accordingly reduced. There has further been a strong feeling towards reducing both these species under $P$. multibracteata. The following long-hand note by $E$. E. Galpin was found on an isotype specimen of $P$. doddii in the Albany Museum: "I am very doubtful as to whether $P$. multibracteata, $P$. flanaganii, $P$. simplex and $P$. doddii are not all varietal forms of one species. The length of the scaly stipes supporting the flower head and causing it to be either pedunculate or sub-sessile, from examination of specimens of $P$. multibracteata from the same spot appears to me to be a matter of luxuriance". Galpin had a profound knowledge of plants in the field. Support has now been lent 
to his view by the reduction of $P$. flanaganii partly under $P$. multibracteata and of $P$. doddii under $P$. simplex, leaving us with two species, one arborescent and one dwarf, which clearly stand in a special relation to each other.

The ranges of these two species are almost identical and they almost invariably accompany one another in the same locality, the main exceptions being in the Natal Drakensberg where simplex forms are rare, and in Swaziland where $P$. multibracteata is absent. A few of the herbarium specimens seem to be intermediate and intermediate forms have been found in the wild though unfortunately always sterile. There is a sharp distinction between the species in stature and habit: otherwise the only difference in vegetative and floral characters is in size, all parts being proportionately smaller in $P$. simplex. It is suspected that $P$. multibracteata carries a gene for miniature habit, which may be selected by veld burning, leading to the establishment of dwarf populations which are genetically incapable of assuming an arborescent habit even if protected against veld fires. This theory is being tested experimentally. In the meantime, pending clarification of the relationship between them the two species are conserved separately.

10. P. transvaalensis Phillips in Kew Bull. 1911: 84; Phillips in F.C. 5: 587 (1913); Burtt-Davy in Fl. Transv. 211 (1926).

Type: Pietersburg, Burtt-Davy 5179 (K, holo.!).

A small dwarf shrub with numerous ephemeral simple stems $20-30 \mathrm{~cm}$ long arising from an underground rootstock. Stems $4 \mathrm{~mm}$ thick, glabrous, pale green or pink. Leaves spaced along the stems, sessile, bright green, black when dried, linear-elliptic to oblong, $1 \cdot 5-3 \cdot 5 \mathrm{~cm}$ wide by $7-12 \mathrm{~cm}$ long (average about $2 \times 8 \mathrm{~cm}$ ), apex obtuse, base cuneate: blade erect and somewhat stiffened, glabrous, midrib yellow or red-veined, prominent both sides, secondary venation ditto, margin translucent. Heads solitary, terminal, $6 \mathrm{~cm}$ long and as much in diameter, narrowly cylindrical-turbinate, pedunculate with a small stipes $0.5 \mathrm{~cm}$ long, or virtually sessile opening to $130^{\circ}$ at anthesis. Receptacle convex, $15 \mathrm{~mm}$ wide. Bracts only 4-seriate, pale green, glabrous, the innermost commonly pink-tipped and with a fugacious russet pubescence in the upper part, up to $2 \mathrm{~cm}$ broad and $5 \mathrm{~cm}$ long, acute, equalling the flowers. Perianth white, fulvously hairy within the tube, the lip clothed at first with fugacious tawny hairs, otherwise glabrous; $4.5 \mathrm{~cm}$ long of which $15 \mathrm{~mm}$ for the base, $15 \mathrm{~mm}$ for the broad tube and 15 $\mathrm{mm}$ for the lip; teeth indistinct, laterals $1 \mathrm{~mm}$ long. Anthers linear, $10 \mathrm{~mm}$ long. Style white, $5 \mathrm{~cm}$ long, glabrous, terete: stigma pinkish, $8 \mathrm{~mm}$ long, passing almost imperceptibly into the style. Ovary $3 \mathrm{~mm}$ long. Fruit $10 \mathrm{~mm}$ long, clothed with golden-brown hairs.

Flowers in summer.

This is a small low-growing species found in mountain grasslands of the Haenertsburg area.

There is some confusion as to the type locality. The sheet bearing the type at Kew (Burtt-Davy 5179) is marked "Goedgeluk, Zoutpansberg" and is so cited in F. Cap. However, in Fl. Transv. 1: 211 Burtt-Davy cites his own number 5179 as "Pietersburg, Houtboschberg" while his register says "hillsides above Diepkloof". We have not been able to trace any such locality at Goedgeluk, but the farm Diepkloof is a short distance to the north of the Houtboschberg. The type therefore evidently came from somewhere on the Woodbush ridge.

Transvaal.-Pietersburg District, Haenertsburg area: Houtboschberg, BurttDavy 5179; Suikerbosrand, Thompson s.n.; Beard 858; Iron Crown, Beard 860; Wolkberg, Beard 862; Meeuse 9861. 
11. P. gaguedi Gmel. in Ed. 13, Linn. Syst. Nát. 2,1: 225 (1791).

Protea abvssinica Willd. in Species Plantarum 1: 522 (1708). R. Brown in Trans. Linn. Soc. 10: 85 (1810); Richard in Tent. Fl. Abyss. 2: 232 (1851); Meisner in DC. Prodr. 14: 237 (1856); Phillips in F.C. 5: 581 (1913); Baker and Wright in F.T.A. 6, 1: 199 (1913); Bews in Fl. Natal \& Zululd. 82 (1921); Burtt-Davy in Fl. Transv. 211 (1926).

Type: none appears to have been preserved.

P. trigona Phillips in Kew Bull. 1910, 230.

Type: Pretoria, Leendertz 679 (PRE, iso.!).

Gaguedi (nom. vern.) Bruce, Abyss. 5: 52 (1790).

Small gnarled tree not exceeding (in South Africa) $4 \mathrm{~m}$ in height, generally $2 \mathrm{~m}$, less in adverse situations. Trunk $10 \mathrm{~cm}$ in diameter with pale brown, flaky, bark. Flowering branchlets $8-10 \mathrm{~mm}$ thick, drying to $5 \mathrm{~mm}$, pubescent when young, soon glabrous and developing a thin dehiscent and papery bark cracking to show a reddish mealy surface beneath. Leaves sessile, closely ranked, light green, linear-lanceolate or -oblanceolate, $1 \cdot 5-3 \mathrm{~cm}$ wide by 9-18 cm long (average about $2 \times 12 \mathrm{~cm}$ ), 4-8 mm broad at the base, sometimes slightly falcate, apex obtuse, base cuneate, blade leathery, glabrous except in extreme youth when it may be densely pubescent, midrib yellow, prominent both sides, secondary venation finely reticulate, prominent both sides in dried specimens, no distinct marginal vein. Heads solitary, terminal, varying considerably in size from 4-10 $\mathrm{cm}$ in length and as much in diameter, broadly globose, generally pedunculate with a well marked scaly stipes $1.5 \mathrm{~cm}$ long, though some heads are virtually sessile: opening to $160^{\circ}$ at anthesis. Receptacle slightly convex, $15 \mathrm{~mm}$ wide. Bracts about 6-seriate above the stipes, pale green with dense silvery pubescence, sometimes rose tinted above, $2 \mathrm{~cm}$ wide at their broadest, up to $4 \mathrm{~cm}$ long, much shorter than the flowers, obtuse with short white ciliate fringe. Perianth densely hairy, the base and tube whitish or fulvous, lip pure white or rose tinted, $5 \mathrm{~cm}$ long of which 1 $\mathrm{cm}$ for the base, $2 \mathrm{~cm}$ each for the tube and lip; tube glabrous within, lip covered with shaggy hairs except on the back which is glabrous or almost so, or with a line of hairs along the median keel; teeth not readily distinguishable, about $1 \mathrm{~mm}$ long. Anthers linear, $10 \mathrm{~mm}$ long. Style white, about $6 \mathrm{~cm}$ long, glabrous, flattened or triangular below, terete above: stigma white, slender, $6-10 \mathrm{~mm}$ long, passing with a slight bend, into the style. Ovary $3 \mathrm{~mm}$ long. Fruit $1 \mathrm{~cm}$ long clothed with pale golden-brown hairs.

Flowering mainly in winter.

$P$. gaguedi Gmel. ranges right through tropical Africa as far as Abyssinia, where it was first found and described. "Gaguedi" is a vernacular name in those parts. In the Union, it follows the eastern escarpment, with interior outliers only on the Magaliesberg, right down from the Zoutpansberg into Zululand where a collection of the writer's establishes its extreme southerly limit at the gorge of the Insuzi river in the Nkandhla district, just north of the Tugela. Sometimes this species is found within the North East Highland Sourveld, often just outside it, under rather drier and hotter conditions merging to Bushveld. It seems to demand less rainfall than others and is generally found on the rockiest of ground.

\section{Selected Citations.}

Natal.-Utrecht: Thode A385. Ngotshe: Louwsburg, Dyer 5029. Nkandhla: Insuzi River, Beard 799.

SwazILAND.-Mbabane: Miller 5142. 
TransvaAl.-Soutpansberg: Makonde, van Warmelo 5117/9. Pietersburg: Wolkberg, Gerstner 5607. Pilgrim's Rest: Galpin 14312. Barberton: Thorncroft 3061. Pretoria: Leendertz 679. Rustenburg: Pegler 941.

This species is the subject of the only name change effected in this paper, being the one hitherto known in South Africa as $P$. abyssinica Willd. The evidence supporting this ehange is as follows. A plant in the vicinity of Lamalmon, Abyssinia, was described in semi-technical terms under its native name Gaguedi by Bruce in his "Travels to Discover the Source of the Nile" 1790, with two illustrations. This plant was named scientifically as Protea gaguedi by Gmelin in his edition (No. 13) of Linnaens' Syst. Nat. in 1791 and as Protea abysinica by Willdenow in Species Plantarum, 1798. As both authors made it clear that they were describing Bruce's plant, there is no doubt that $P$. gaguedi is the valid name. We next have to decide whether our South African plants are conspecific with Bruce's, which might be a thorny problem since the eighteenth century descriptions are of the briefest and vaguest and Bruce's illustrations are stylised and might be almost any Protea. Fortunately, only one species of Protea has ever been collected in Abyssinia and we can thus be tolerably certain that it is $P$. gaguedi. South African specimens believed to be $P$. gaguedi have been compared at Kew with Abyssinian material by Mr. D. J. B. Killick at the writer's request and pronounced identical. $P$. trigona Phillips is now reduced to synonymy under $P$. gaguedi after examination of an isotype in the Transvaal Museum collection.

12. P. hirta Klotzsch in Flora, 76 (1845) and Beitrag Fl. Kap.- und Natal, 140 (1846), aggregate species.

Shrub or small tree, up to $3 \mathrm{~m}$ in height, rarely in dwarf form with underground rootstock emitting numerous stems up to $70 \mathrm{~cm}$ tall, almost invariably simple. Stems pale green to brown or silvery when young, densely hirsute, at length brown and glabrous, up to $10 \mathrm{~mm}$ thick. Leaves sessile, numerous, russet-green, oblong to oblanceolate, $2-3.5 \mathrm{~cm}$ wide by $6-12 \mathrm{~cm}$ long (average about $3 \times 10 \mathrm{~cm}$ ), apex rounded or acute, base broad, rounded and even slightly auriculate: blade leathery, densely clothed with fine silky white hairs, and with longer russet hairs on the lower half of the midrib and base: midrib prominent both sides, secondary veins not numerous, irregular, prominent both sides, uniting to form an irregular marginal vein. Heads terminal or lateral, solitary or clustered, 4-6 cm long and $5-7 \mathrm{~cm}$ in diameter when fully open, conical, generally pedunculate with a small scaly stipes $1 \mathrm{~cm}$ long: opening to $180^{\circ}$ at anthesis. Receptacle slightly convex, $12 \mathrm{~mm}$ wide. Bracts $4-8$ seriate above the stipes, russetgreen to yellow, often pink in bud, densely silky-tomentose, $12 \mathrm{~mm}$ wide at their broadest, up to $3 \mathrm{~cm}$ long and equalling or only slightly shorter than the flowers, obtuse, shortly ciliate at the tip. Perianth densely whitish-hairy, 3-5 cm long of which $8-10 \mathrm{~mm}$ for the base, $10-20 \mathrm{~mm}$ for the tube and $12-20 \mathrm{~mm}$ for the lip; tube glabrous within, lip covered with shaggy hairs except on the back which is glabrous or almost so, or with a few hairs along the median keel; lateral teeth 2-3 mm long, intermediate much shorter, tufted with russet hairs. Anthers linear, $6 \mathrm{~mm}$ long, connective shortly produced into a capitate gland. Style white, $3-5 \mathrm{~cm}$ long, flattened, curved; stigma $6-8 \mathrm{~mm}$ long, filiform, passing with an S-bend into the style. Ovary $4 \mathrm{~mm}$ long. Fruit $6 \mathrm{~mm}$ long, clothed with pale, straw-coloured hairs.

Flowering in mid-summer to autumn.

$P$. hirta, aptly "the hairy Protea" was the earliest of the summer rainfall Proteas to be discovered, collected in Natal by Krauss at the early date of 1838. The type locality, ad radicem montium Tafelberge prope fluv. Umlaas, Natal, alt. 800-1,500 ft. (bunt. Sandstein), is thought to be somewhere near Mariannhill. For some ime there was doubt as to the identity of Transvaal plants which do not conform entirely to the Natal type. This difficulty has been resolved by the foundation of a new subspecies, glabrescens. In the course of fieldwork in Rhodesia and East Africa it became clear 
that $P$. hirta also extended there, although it had hitherto been classified under a number of different names. After examination of the types of these species they can now be reduced to synonymy under the aggregate species though more field work will be required before they can be divided into subspecies. These are:

Southern RhodesiA.- $\boldsymbol{P}$. swynnertonii S. Moore in J. Linn. Soc. Bot. 40: 184 (1911). The type (Swynnerton 1411) can no longer be found at the British Museum. From description, however, and from collecting in the type locality, there is no hesitation in reducing the species.

AngOla.-P. welwitschii Engl., Hochgebirgsfl. Trop. Afr. 196 (1892). The syntypes, (Welwitsch 1600 and 1602 B) show somewhat narrow leaves and if this proves typical of Angola specimens, recognition of a subspecies will be appropriate.

Belgian Congo (Katanga).-P. obtusifolia de Wild. in Ann. Soc. Sc. Brux. 40, 2: 84 (1921) non Buek ex Meisn. in DC. Prodr. (1856). This was reduced to synonymy under $P$. goetzeana Engl. by Hauman in Bull. Jard. Bot. Brux. 17 (1946). In any case the name is illegitimate, being preoccupied.

Type: Homble 1253 (BR).

Belgian Congo.-P. congensis Engl. Jahrb. 33: 129 (1904).

Type: Descamps s.n. (B).

Uganda.- $P$. melliodora Dale in Indigenous Trees of the Uganda Protectorate, non Engler \& Gilg. Greenway \& Eggeling 7069 (EA).

TANGANYIKA.- $P$. goetzeana Engl. Jahrb. 30: 298 (1902).

Type: Goetze 1367 (B).

P. eickii Engl. Jahrb. 33: 130 (1904).

Type: Eick 39 (B).

It is probable that we must also include:

TANGANYIKA.- $P$. uhehensis Engl. Jahrb. 27: 380 (1901).

Type: Goetze 720 (B). This specimen has an abnormally large head.

I have no doubt that all these forms represent a single, widespread, variable species. They are united by such characters as the unusually pale, straw-coloured seed hairs (which unfortunately darken with age so that this is unreliable in the herbarium) and the triangular appendage to the anthers.

(a) subsp. hirta.

P. hirta Klotzsch in Flora, 67 (1845) and Beitrag Fl. Kap.- und Natall, 140 (1846);

Meisn. in DC. Prodr. 14: 236 (1856); Medley Wood in Pl. Natal 3: t. 218 (1902);

Phillips in F.C. 5: 582 (1913) in part; Bews in Fl. Natal \& Zululd. 82 (1921).

Type: Umlaas Riv., Krauss 202 (B, holo.!).

Growing as it does at the extreme southerly limit of the range of the species, this subspecies exhibits reduction in size and is commonly found as a low shrub less than $1 \mathrm{~m}$ high, often with numerous ephemeral stems arising from a rootstock. Stems only $5 \mathrm{~mm}$ thick. Leaves as for aggregate species. Heads generally solitary and terminal only, 4-5 cm long, bracts 4-5-seriate. Perianth $3 \mathrm{~cm}$ long of which $8 \mathrm{~cm}$ for the base, $10 \mathrm{~mm}$ for the tube and $12 \mathrm{~mm}$ for the lip. Style $3.5 \mathrm{~cm}$ long, stigma $6 \mathrm{~mm}$.

A rare plant, found in the Natal Coast belt from Umzinto to Nkandhla on outcrops of Table Mountain Sandstone, and still more rarely on the eastern Transvaal escarpment.

NatAL.-Pietermaritzburg: Table Mt., McClean 165; Sim 19402. Umvoti: Seven Oaks, Beard 727; 772; 883. Umzinto: Dumisa, Fairfield, Bayer 1418. Pinetown: Blackhill, Hesom s.n. Near Umlaas River: Krauss 202. Spring Grange, Platt s.n. Springfield: Moonsamy s.n. Kloof: Dohse Landell and Shepherd 39. Inanda: Medley Wood 577. Nkandhla: Wylie in herb. Medley Wood 8757.

TransvaAL. - Lydenburg: Beard 875. 
(b) subsp. glabrescens Beard, subsp. nov.

P. hirta sensu Phillips in F.C. 5: 582 (1913) in part; sensu Burtt-Davy in Fl. Transv. 211 (1926).

Type: Pretoria, Meeuse 9052 (PRE, holo.!).

Frutex ramosus a subspecie hirta foliis minoribus demum manifeste glabrescentibus, capitulis majoribus saepe lateralibus et fasciculatis differt.

This subspecies is characterised as follows:-

A divaricate shrub generally about $1 \mathrm{~m}$ heigh, sometimes rather less, sometimes up to $3 \mathrm{~m}$. Branchlets $5-10 \mathrm{~mm}$ thick. Leaves oblong to oblanceolate, very variable as to size from 12-25 mm in width and 6-12 cm long, (average about $2 \times 8 \mathrm{~cm}$ ), apex obtuse, base attenuate; blade coriaceous, densely pubescent in youth, at length apparently glabrescent but with closely adpressed fine silky hairs, especially on the base of the midrib. Heads terminal or lateral, very commonly in groups of two to four or more, 4-6 cm long. Bracts 5-8-seriate, often pink in bud, russet to yellow with fine silvery pubescence, much shorter than the flowers. Perianth $4-5 \mathrm{~cm}$ long of which 10-12 for the base and 15-20 each for the tube and lip: lateral teeth $3 \mathrm{~mm}$, median $2 \mathrm{~mm}$. Style $5 \mathrm{~cm}$ long, stigma $8 \mathrm{~mm}$.

Flowers in summer.

Locally frequent in the Bankenveld and Sour Bushveld of the Transvaal on sandy flats.

\section{Selected Citations.}

TransvaAl.-Middelburg: Smith 3470. Belfast: Machadodorp, Marais 11. Waterberg: Warmbaths, Marloth 3807; Geelhoutkop, Breyer 30236. Potgietersrust: Galpin 8834. Pretoria: Hammanskraal, Codd 7045; Nature Reserve, Meeuse 9052. Rustenburg: Dyer and Verdoorn 3925. Johannesburg: Burtt-Davy 4002. Ventersdorp: Mabaalstad, Louw 1900.

13. P. rubropilosa Beard, sp. nov. holo.!).

Type: Pietersburg Dist., Wolkberg, S. Thompson 828 in herb. J. S. Beard (PRE,

Arbor usque $8 \mathrm{~m}$ alta cortice nigro, ramulis glabris, aereis, $1 \mathrm{~cm}$ crassis. Folia sessilia, obovata, $5 \mathrm{~cm}$ lata, $15 \mathrm{~cm}$ longa, apice rotundata, inferne angustata; lamina glaberrima, nervis utrinque prominentibus. Capitulum $8 \mathrm{~cm}$ longum, sive sessile. Involucri bracteae 7 seriatae supra stipitem, subacutae, extrinsecus dense rubro-pilosae ac margine rubro-ciliatae, usque $5 \mathrm{~cm}$ longae quam floribus multum breviores. Calyx $6 \mathrm{~cm}$ longa, inferne glabra, limbo dense albotomentoso, $2 \mathrm{~cm}$ longo; limbi dentes $3 \mathrm{~mm}$ rubro-cristati. Stylus puniceus, $7 \mathrm{~cm}$ longus, glaber; stigma $12 \mathrm{~mm}$, filiforme.

Gnarled tree with spreading branches up to $8 \mathrm{~m}$ in height and $1 \mathrm{~m}$ in diameter (more commonly $5 \mathrm{~m}$ heigh and $25 \mathrm{~cm}$ in diameter), bark black, flaky. Flowering branchlets $1 \mathrm{~cm}$ thick, glabrous with shiny copper-coloured bark. Leaves sessile, confined to previous season's wood, dark green, obovate, $5 \mathrm{~cm}$ wide by $15 \mathrm{long}$, apex rounded, slightly narrowed towards the base: blade leathery, quite glabrous with a transparent margin; midrib red, prominent both sides, secondary veins irregularly reticulate, prominent both sides (with no marginal vein) in sicco but indistinct in fresh leaves. Heads solitary, terminal, $8-10 \mathrm{~cm}$ long and as much in diameter, globoseeverted, virtually sessile, opening to $90^{\circ}$ at anthesis and thereafter remaining open until the seed is shed. Receptacle convex, $25 \mathrm{~mm}$ wide. Bracts about 7-seriate, rosy-pink, densely rusty-pilose without and ciliate with tawny hairs $1-2 \mathrm{~mm}$ long, the pilosity giving the bracts a bronze metallic sheen; bracts up to $2 \mathrm{~cm}$ broad and $4 \mathrm{~cm}$ long, much shorter than the flowers, acute to rounded. Perianth white with rosy-red 
veins on the tube and lip, $6 \mathrm{~cm}$ long of which $1.5 \mathrm{~cm}$ for the base, 2.5 for the tube and $2 \mathrm{~cm}$ for the lip; base and tube glabrous, lip densely white-tomentose on the sides and keel and recurved at the top: lateral teeth $3 \mathrm{~mm}$, median $1 \mathrm{~mm}$ tufted with rusty hairs. Anthers linear, $12 \mathrm{~mm}$ long, with an apical gland. Style pinkish, $7 \mathrm{~cm}$ long, glabrous, terete; stigma filiform, $12 \mathrm{~mm}$ long, passing abruptly into the style. Ovary $3 \mathrm{~mm}$ long, fruit $1 \mathrm{~cm}$ clothed with reddish hairs.

Flowers in spring, (August to October).

This species is named from the unusually thickly pilose nature of the bracts. It is found along the north-eastern Transvaal escarpment, above 6,000 ft., from Lydenburg to the Wolkberg.

TransvaAl.-Lydenburg, Keet 1123. Mariepskop, Beard 865. The Downs, Rogers 21964. Wolkberg, L. C. Thompson s.n.; Sheila Thompson 828 in herb. J. S. Beard; Schutte s.n. Drakensberg without precise locality, Kilpir N. B. Gard. 1000/31.

\section{P. comptonii Beard, sp. nov.}

\section{Type: Barberton, Compton 19781 (KIRST, Holo.!).}

Arbor ramis glabris $2 \mathrm{~cm}$ crassis. Folia sessilia, aliquot magna, oblanceolata, $4.5 \mathrm{~cm}$ lata, $18 \mathrm{~cm}$ longa, glabra margine rubro, nervulis in sicco utrinque prominentibus. Capitulum grande, $10 \mathrm{~cm}$ longum, sessile. Involucri bracteae 6-seriatae, glaberrimae, subvirides, $5 \mathrm{~cm}$ longae, quam floribus breviores. Calyx alba, glabra praeter lateribus dentibusque limbi dense villosis, $8 \mathrm{~cm}$ longa, limbus dentatus $3 \mathrm{~cm}$, dentibus lateralibus $4 \mathrm{~mm}$ longis rubido-cristatis. Stylus albus, $8 \mathrm{~cm}$ longus, glaber. Stigma album, filiforme, $12 \mathrm{~mm}$ longum.

Gnarled tree up to $5 \mathrm{~m}$ high with a short trunk up to $20 \mathrm{~cm}$ diameter. Bark very thick and corky and longitudinally fissured. Flowering branchlets unusually stout, 1.5-2 cm thick, glabrous with glossy pale brown bark. Leaves sessile, crowded at the end of the branchlets, dark green and fleshy, oblong to oblanceolate, unusually large for this genus, $3-6 \mathrm{~cm}$ wide by $12-24 \mathrm{~cm}$ long (average about $4 \cdot 5 \times 18 \mathrm{~cm}$ ), apex obtuse, often faintly retuse at the tip, base broadly attenuate, lamina $2 \mathrm{~cm}$ broad just above junction with stem; blade stiff, fleshy, quite glabrous, midrib red below, yellowgreen above, prominent both sides, secondary venation inconspicuous in the fresh state, becoming prominent when dry on both sides; margin red, translucent. Heads solitary, terminal, $8-10 \mathrm{~cm}$ long by $10-15 \mathrm{~cm}$ in diameter, virtually sessile, everted, opening to $180^{\circ}$ at anthesis and thereafter remaining wide open until the seeds are shed. Receptacle conical, $2 \cdot 5 \mathrm{~cm}$ wide. Bracts about 6-seriate, pale green, quite glabrous, with a shiny waxy covering, $2.5 \mathrm{~cm}$ wide at their broadest, up to $5 \mathrm{~cm}$ long, very much shorter than the flowers, obtuse, very shortly white-ciliate. Perianth white, glabrous except on the sides, keel and teeth of the lip which are densely villous, $8 \mathrm{~cm}$ long of which $2 \mathrm{~cm}$ for the base, 3 for the tube and 3 for the lip which is $5 \mathrm{~mm}$ broad; lateral teeth $4 \mathrm{~mm}$ long, median tooth $1.5 \mathrm{~mm}$, conspicuously tipped with reddish hairs. Anthers linear, $15 \mathrm{~mm}$ long, apical gland $1 \mathrm{~mm}$. Style white, $8 \mathrm{~cm}$ long, glabrous, terete or very slightly flattened, tapering; stigma white, slender, $12 \mathrm{~mm}$ long, passing with a slight bend into the style. Ovary $3 \mathrm{~mm}$ long, fruit $10 \mathrm{~mm}$, clothed with whitish hairs.

Flowering in autumn and winter, (May to July).

This species bears the name of Professor R. H. Compton, its first collector. It is known only from the mountains above Barberton in the eastern Transvaal, along the road from Barberton to Havelock Mine, altitude 4-5,000 ft., in grass on rocky mountain slopes, associating with $P$. rouppelliae Meisn. and $P$. rhodantha Hook. f., var. falcata Beard.

TransvaAl.-Barberton: Compton 19781; Schelpe 4107; Hamilton 794 and 809 in herb. J. S. Beard. 
15. P. curvata N.E. Br. in Kew Bull. 1901, 131; Phillips in F.C. 5: 580 (1913); BurtDavy in Fl. Transv. 211 (1926).

Type: Barberton, Galpin 973 (K, Lecto., NH, GRA, CTM, BOL, iso.!).

A slender tree up to $6 \mathrm{~m}$ in height, with long ascending branches. Flowering branchlets $1 \mathrm{~cm}$ thick, bark smooth, grey-pink and shortly tomentose in youth, longitudinally wrinkled. Stem up to $15 \mathrm{~cm}$ diameter, bark black, scaly and fissured. Leaves sessile or so long attenuated at the base as to appear petiolate, closely ranked, light green, mostly somewhat falcate, linear-oblanceolate, $10-15 \mathrm{~mm}$ wide by $10-20 \mathrm{~cm}$ long (average about $1.3 \times 15 \mathrm{~cm}$ ), apex obtuse, long attenuated to $2-3 \mathrm{~mm}$ wide at the base: blade leathery, glabrous; midrib prominent both sides, secondary venation indistinct, irregular; blade with translucent cartilaginous margin. Heads solitary, terminal, 6-7 cm long and as much in diameter, globosely everted, pedunculate with a short scaly stipes $5 \mathrm{~mm}$ long, opening to $180^{\circ}$ at maturity and thereafter remaining fully opened till the seed is shed. Receptacle conical, $2 \mathrm{~cm}$ wide. Bracts about 4-seriate above the stipes, grey-tomentose on the lower half, glabrous above, deep red in colour, $15 \mathrm{~mm}$ wide at their broadest, up to $4 \mathrm{~cm}$ long, very much shorter than the flowers, obtuse to sub-acute, minutely ciliate. Perianth rose-pink, pubescent except on the lower part of the base, and the upper part of the back of the lip, $5 \mathrm{~cm}$ long of which $1 \mathrm{~cm}$ for the base, $2 \mathrm{~cm}$ each for the tube and lip; tube pubescent within; lateral teeth $3 \mathrm{~mm}$ long, tomentose except at the glabrous tips, median tooth $2 \mathrm{~mm}$ filiform. Anthers linear, $15 \mathrm{~mm}$ long, with an apical gland. Style pink, about $6 \mathrm{~cm}$ long, flattened below, trigonous above, glabrous: stigma red, slender, $10 \mathrm{~mm}$ long, obtuse, passing with a slight bend into the style. Ovary $2 \mathrm{~mm}$ long. Fruit $1 \mathrm{~cm}$ long, and $5 \mathrm{~mm}$ thick at top, clothed with long red to yellow-brown hairs.

Flowers in winter, (June to July).

This extraordinary tree, so peculiar in appearance and habitat, confined as it is to a single koppie in the bushveld below Barberton, was first collected by Galpin in 1895 , his specimen forming the basis of N. E. Brown's description in 1901. It was collected again by Thorncroft in 1919. The locality given in Galpin's register is vague, "Kaap River Valley, 2,500-3,000 ft.". However the labels of all the specimens in the South African herbaria, though of the same number and written up in Galpin's handwriting, bear in many cases different data as to locality. The one in the Natal Herbarium has "Caledonian" which is a siding five miles north of Barberton and with this direction Dr. P. D. Hamilton was enabled to rediscover the type locality in 1956. The precise spot is a koppie formed by an outcrop of talcose schist, rising from the north bank of the Suidkaap River slightly downstream from Caledonian. As far as is known the species is confined to this single locality, in a bushveld association with Acacia spp., Pavetta edentula, Combretum transvaalense, C. apiculatum and Bolusanthus speciosus.

TransvaAl.-Barberton: Galpin 973; Thorncroft 1053; Hamilton 832; 884 in herb. J. S. Beard.

\section{RePUted Hybrid Forms.}

$P$. hirta $X P$. simplex. A number of plants exist in a mixed population of the parental species near the Catholic Mission, Canema, Seven Oaks, Natal: Dyer 4144, Beard $773 ; 774$.

P. gaguedi $X P$. rhodantha. Along road from Barberton to Havelock Mine six miles from the Barberton-Kaapmuiden main road, a single plant: Meeuse 10108 (1957). Both parental species present-Meeuse 10107, P. rhodantha; 10109, P. gaguedi. 
DoubTful ReCORDs.

P. tenax, R. Br. Rogers 28291 (PRE), Culvers, Weenen, Natal. As this species has only otherwise been collected in the False Macchia of the Eastern Province, it is supposed that an error in labelling the specimen may have occurred.

P. grandiflora, Thunb. Rogers 22298 (PRE), Rustenburg. The locality is thought to be incorrect as in the case of the above.

\section{ACKNOWLEDGMENTS.}

The writer is indebted to the Chief and staff of the Division of Botany, and to Prof. A. W. Bayer and the staff of the Botany Department, University of Natal, for advice, encouragement and assistance; and to the Division of Botany for assistance in the matter of field work. 



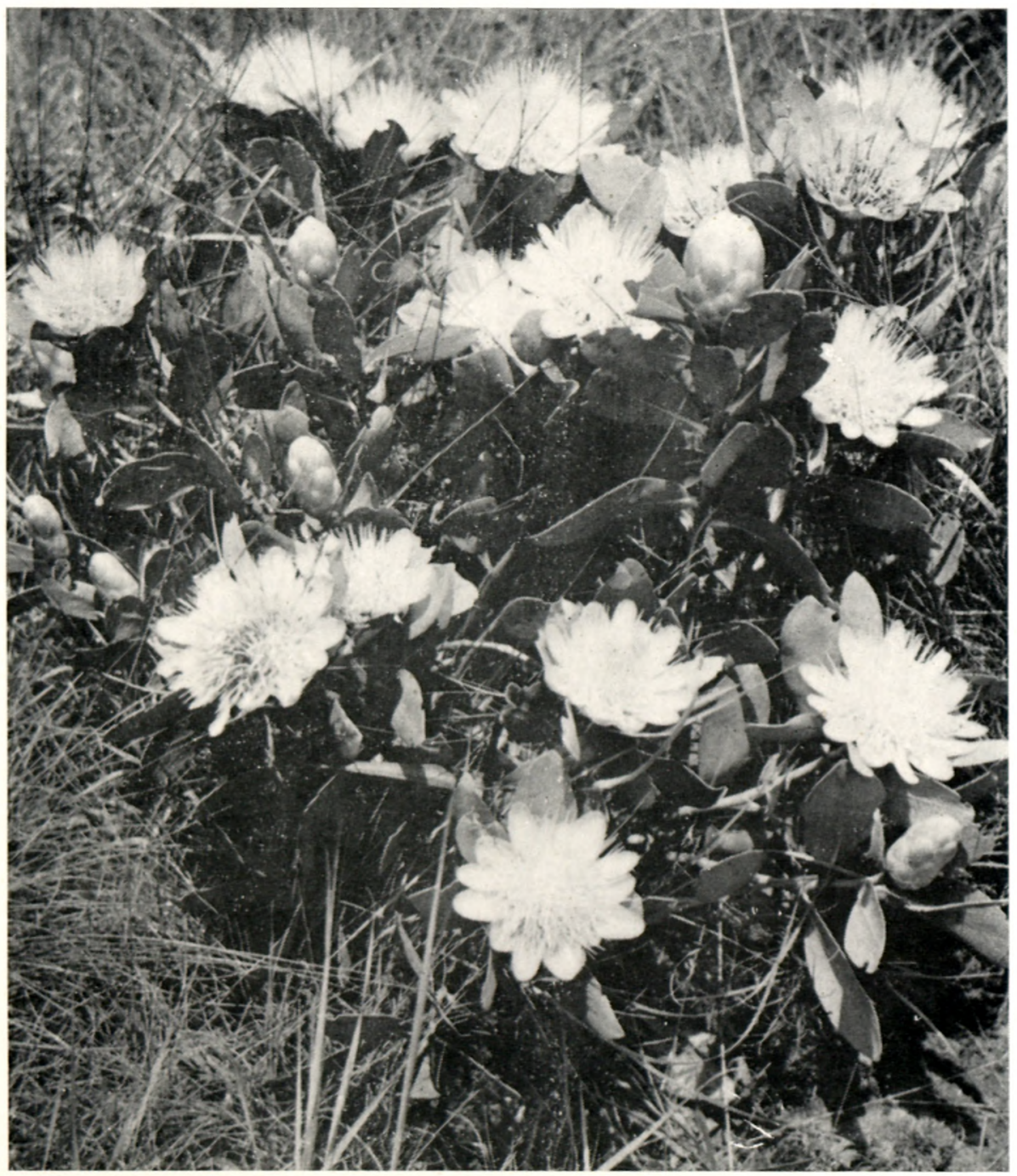

Plate I.-Protea dracomontana Beard 
